\title{
Creative Corporate Communication in Social Media - How to Effectively Build Relations and Receive High Quality Resumes From Younger Generations
}

\begin{abstract}
Barbara Drapata*
Nowadays, companies increasingly often face the dilemma of how to reach and recruit younger people. The goal of this paper is to present different values, important for every generation still active on the labour market, and to present the content attributes influencing the response to recruitment posts and the number of obtained resumes. The paper uses quality analyses in the form of a case study in order to analyse social media recruitment campaigns of the chosen marketing agency. The discussion is divided into three parts. The first part covers the analysis of the form, type of content and message, used by a given brand in recruitment announcements posted in social media. As a result, the content attributes were identified (format, application form, readability, offer length, use of hashtags and emojis, cohesion of the message and analysis of requirements, benefits and added values). The second part covers the analysis of results of these paid recruitment announcements. The third part uses a deductive approach in a form of empirical analysis covering the preliminary logical analysis of results (Zaborek, 2007). By means of analytic generalisation, the author wants to present preliminary conclusions regarding the effectiveness of recruitment campaigns targeted at young generations and demonstrate interrelations between individual content attributes and engagement of users in the posts and resumes received by the company from potential candidates. The analysis indicates that younger generations (Generations $Y$ and $Z$ ) do not share the same values as the older generations (the so-called Baby Boomers and Generation X). This is probably due to the fact that the younger generations entered the labour market at different economic times, were brought up in a different spirit and differently function in the world.
\end{abstract}

Keywords: social media, corporate communication, employer branding, recruitment, generation.

Submitted: 29.08 .18 | Accepted: 02.11.18

\section{Kreatywna komunikacja korporacyjna w mediach społecznościowych - jak skutecznie budować relacje i zdobywać jakościowe życiorysy od młodych pokoleń}

$W$ dzisiejszych czasach firmy maja coraz większy problem z dotarciem do młodych ludzi $i$ zatrudnieniem ich. Celem artykutu jest zaprezentowanie odmiennych wartości, które sa ważne dla pokoleń aktywnych na rynku pracy oraz przedstawienie atrybutów contentów wply-

\footnotetext{
* Barbara Drapała - master's degree, Head of Social Media at Performics. https://orcid.org/0000-00024611-9555.

Correspondence address: Performics, Domaniewska 44A Street, 02-672 Warsaw, Poland; e-mail: barbara.maria.drapala@gmail.com.
} 
wajacych na zaangażowanie wobec postów rekrutacyjnych i liczbę pozyskanych życiorysów. $W$ artykule wykorzystano badania jakościowe $w$ formie studium przypadku, aby przeanalizować kampanie rekrutacyjne $w$ mediach spotecznościowych wybranej agencji reklamowej. Rozważania sktadaja się z trzech części. Pierwsza część dotyczy analizy formy, rodzaju treści i przekazu działań stosowanych przez wybrana markę $w$ ogtoszeniach rekrutacyjnych zamieszczanych w mediach spotecznościowych. Na tej podstawie wyszczególniono atrybuty treści (format, sposób aplikowania, czytelność, dtugość ogtoszenia, zastosowanie hashtagów i emotikonów, spójność komunikatu oraz analize wymagań, benefitów i wartości dodanych). $W$ drugiej części przeanalizowano zaś wyniki dziatań ptatnych tychże ogtoszeń rekrutacyjnych. Natomiast $w$ trzeciej części wykorzystano podejście dedukcyjne $w$ formie badania empirycznego obejmujace wstępna logiczna analize wyników (Zaborek,2007). Autorka poprzez generalizacje analityczna chce zaprezentować wstępne wnioski dotyczace skuteczności kampanii rekrutacyjnych skierowanych do młodych pokoleń oraz wykazać zależności pomiędzy poszczególnymi atrybutami treści a zaangażowaniem użytkowników wobec postów i otrzymanymi przez firmę życiorysami potencjalnych kandydatów. Analiza wskazuje, że mtode pokolenia (Y $i \mathrm{Z})$ wyznaja inne wartości niż starsze pokolenia (wyżu demograficznego i X). Prawdopodobnie wynika to $z$ faktu, że pokolenia te wchodzity na rynek pracy $w$ innym okresie gospodarczym, wychowywaty się $w$ innym duchu i funkcjonuja w odmienny sposób w otaczajacym je świecie.

Słowa kluczowe: media społecznościowe, komunikacja korporacyjna, budowanie wizerun$\mathrm{ku}$ pracodawcy, rekrutacja, pokolenia.

Nadesłany: 29.08.18 | Zaakceptowany do druku: 02.11.18

JEL: M14, M31, M51

\section{Introduction}

Nowadays, the Internet is becoming a more and more popular medium used for recruitment and selection of employees (Cober et al., 2004b). This is due to the fact that it gives companies and HR specialists a wide range of tools that allow transferring and acquiring a lot of data about those seeking employment, working within an organization or in a rival company. What is more, websites (Williamson et al., 2010) and social media (Bizzi, 2018) are the key source of information about a given employer.

Research by Tiago and Verissmo (2014) showed that $82 \%$ of employees think that digital presence in social media promotes internal and external relations. Companies noticed that appropriately organized actions in social media present them in an attractive light. Moreover, via the social media, they are able to reach potential employees and they can also use them as a recruitment tool, especially when it comes to younger generations (Cho et al., 2013). Tests performed on a sample of 800 employers revealed that $94 \%$ of them intended or actually used social media in their recruitment processes; $78 \%$ of the examined companies already hire employees with the help of social media (Jobvite,2013).

This data shows that the role and significance of social media in creating brand image, as well as in recruitment processes, are getting greater and greater. However, two issues should be distinguished. On the one hand, companies understand how important the social media are (Raport Media społecznościowe w rekrutacji 2017; Jansen et al., 2005; Kerrin, 2005). On the other, they often are not able to adjust the message to the target group (Drapała, 2019; Karim et al., 2015; Universum Students Survey, 2018). The goal of this article is to present different values, important for every generation still active on the labour market, and to specify the content attributes that companies should use in recruitment advertisements in order to build relations and recruit new employees.

\section{Literature Review}

The social media are becoming more and more often one of the elements of strategic communication while fulfilling the mission of every organization (Hallahan et al., 2007). Moreover, social media allow us to carry out operations charac- 
teristic of relationship marketing, which is based on establishing contact and creating a bond with the customers (Berry, 1983; Levitt, 1983). Grönroos (1994) thought that relationship marketing includes actions that should "establish, maintain, and enhance relationships with customers and other partners, at a profit, so that the objectives of the parties involved are met. This is achieved by a mutual exchange and fulfilment of promises". Empirical studies confirm that marketing actions based on relationship building have better results than transaction-oriented actions (Palmatier et al., 2006). Relationship marketing glorifies two-way communication made available by the social media because this strengthens the position of the consumer to whom companies need to present a more individualistic and subjective approach (Wiśniewski, 2016).

Actions based on intrusion are becoming less significant. But then, other actions are becoming more and more important, like those based on attraction, and sometimes even on deception, which arouse interest in their contents only loosely connected to a given brand and referring to the offer on a minimum level (Martin \& Smith, 2008).

Moreover, there is also inbound marketing, understood as carrying out actions allowing the receiver to interpret the message individually and interact with it, which creates long-term two-way communication (David, 2010).

Companies that create communication strategies based on relationship marketing should also take into consideration the peculiarity of the target group, its values and channels used by this group. Table 1 shows, for instance, that Generation $\mathrm{Z}$ is the most willing to use Facebook and the least willing to use LinkedIn. This is vital for the companies conducting recruitment campaigns targeted at this group. Although LinkedIn is recognized as a channel intended for building a network of contacts and seeking a job, it is used by very few representatives of Generation Z. Consequently, an employer who wants to hire people from Generation Z should focus on less formal channels such as Facebook or Instagram.

The analysis presented in Table 2 indicates that younger generations (Generations $\mathrm{Y}$ and $\mathrm{Z}$ ) pay attention to other aspects of work and do not share the same values as the older generations (the socalled Baby Boomers and Generation X). This is probably due to the fact that those generations entered the labour market at different economic times, were brought up in a different spirit and differently function in the world.

What is more, the members of every generation are in a different phase of life: early adulthood, middle phase of adulthood (35-49 years), late adulthood (50-64 years) and senior years (65-74 years) (Trębała et al., 2004). Therefore, their psychological and economic needs are different. Generation $\mathrm{Z}$ is just entering the labour market and is often still financially supported by their parents. This may contribute to the fact that people of this generation arrive at the decision to change workplace more freely. Besides, informal atmosphere in the workplace and access to social media is also important to them. Generation Y strives to become independent and attaches great weight to investing in self-development; therefore, it is very important that recruitment announcements mention the possibility to take part in training, workshops, etc. This generation is also in the reproductive

Table 1. Number of social media users in Poland

\begin{tabular}{|l|c|c|c|c|}
\hline $\begin{array}{c}\text { Generation / Number } \\
\text { of channel users }\end{array}$ & Baby Boomers & Generation X & Generation Y & Generation Z \\
\hline Facebook & $1,300,000$ & $4,500,000$ & $4,600,000$ & $3,700,000$ \\
\hline Instagram & 140,000 & 880,000 & $1,300,000$ & $1,900,000$ \\
\hline LinkedIn & 27,000 & 280,000 & 460,000 & 260,000 \\
\hline Twitter & 91,000 & 37,700 & 390,000 & 455,000 \\
\hline Snapchat & - & - & 900,000 & $1,700,000$ \\
\hline
\end{tabular}

Source: Own study based on data of marketing panels of individual social media (01.01.2018).

Wydział Zarządzania UW https://doi.org/10.7172/1733-9758.2018.29.10 
Table 2. Generations active on the labour market

\begin{tabular}{|c|c|c|c|c|}
\hline Generation & Baby Boomers & Generation X & Generation Y & Generation $\mathrm{Z}$ \\
\hline Birth year & 1946-1964 & 1965-1979 & 1980-1994 & 1995-2000 \\
\hline Age & $72-54$ & $53-39$ & $38-24$ & $23-18$ \\
\hline Weaknesses & $\begin{array}{l}\text { - They feel uncomfortable in } \\
\text { conflicts }\end{array}$ & $\begin{array}{l}\text { - They tend to be distrustful } \\
\text { of their managers } \\
\text { - Not multitaskers } \\
\text { - Tendency to question } \\
\text { authorities }\end{array}$ & $\begin{array}{l}\text { - Unrealistic expectations, value their } \\
\text { own comfort over their employer's } \\
\text { expectations } \\
\text { - Have problems in interpersonal } \\
\text { communication in multi-generation } \\
\text { teams }\end{array}$ & $\begin{array}{l}\text { Might have problems with } \\
\text { concentration, it's hard to } \\
\text { keep them in one place for } \\
\text { long }\end{array}$ \\
\hline
\end{tabular}


phase and feels the need to start a family. As a consequence, it would be worth emphasizing such benefits as a kindergarten in the company or holiday packages for kids. On the other hand, the members of Generation X are people whose children are growing up and becoming independent. They are focused on themselves, their needs and work-life balance. The members of the Baby Boomers Generation are in the pre-retirement age and they are not eager to change workplaces.

This analysis shows that while drafting a recruitment announcement, the employer should think about which generation fits the requirements of the job and then adjust the message, form and channel to that target group.

\section{Methodology}

The paper uses quality analyses in the form of a case study in order to investigate social media recruitment campaigns of the chosen marketing agency. The subject of measure was the analysis of form content type and message of recruitment campaigns carried out on Facebook by Performics (Publicis Media) from March 2017 to December 2017.

On such basis, the content attributes were identified (format, application form, readability, offer length, use of hashtags and emojis, cohesion of the message and analysis of requirements, benefits and added values).

The next stage involved consideration of the results of paid recruitment campaigns and verifications of formulated hypotheses in empirical research covering a preliminary logical analysis of results (Zaborek, 2007) in order to establish whether there is an interrelation between individual content attributes and engagement of users in the posts and resumes received by the company from potential candidates.

\section{Research question:}

To what extent are the individual content attributes interrelated with the engagement of younger generation users in the recruitment posts and the number of gathered resumes?

The examination relates to the assumptions of research concerning analysis of marketing actions which aimed to establish relationships (Palmatier et al., 2006) and those based on deception (Martin \& Smith, 2008). According to Palmatier et al. (2006), marketing actions that are to establish relationships are more effective than those of strictly sales profile, which, for the purpose of this analysis, are considered those of strictly recruitment profile, i.e. based fully on the recruitment process. In other words, such an announcement is focused only on requirements, shows possible benefits of working for a given employer but it does not establish a relationship and has no added value either. The deception profile, presented by Martin and Smith (2008), on the other hand, should be interpreted as actions only loosely connected with the brand and related to a job offer on a minimum level.

The effectiveness of recruitment campaigns is measured as the engagement in recruitment posts and the number of received resumes.

Consequently, the author would like to verify whether the actions consisting in establishing relationships are more engaging than actions focused strictly on sales (strictly of recruitment profile).

In other words, actions consisting in establishing relationships involve greater activity concerning posts (they build greater engagement in posts) than actions focused strictly on sales (strictly of recruitment profile).

Moreover, the author would like to check whether actions consisting in establishing relationships allow acquiring a higher number of resumes than those focused strictly on sales (strictly of recruitment profile).

Another analysed aspect will cover verification of whether actions based on deception are more engaging than those focused strictly on sales (strictly of recruitment profile).

In other words, actions consisting in deception involve greater activity concerning posts (they build greater engagement in posts) than actions focused strictly on sales (strictly of recruitment profile).

Furthermore, it will be verified if actions based on deception allow acquiring a higher number of resumes than those focused strictly on sales (strictly of recruitment profile).

\subsection{Procedures}

The study covered the recruitment campaigns carried out on Facebook in 2017 
by Performics (Publicis Media). The job offers were promoted by the author of this paper, which is why the said company has been chosen. Four campaigns, carried out in various periods of the year (17.03.2017, 03.08.2017, 16.11.2017, 14.12.2017), are subject of the analysis. The tool for measurement is the analysis of content attributes, results of paid actions and empirical research covering the preliminary logical analysis of results in order to establish whether there is an interrelation between individual content attributes and engagement of users in the recruitment posts and resumes received by the company from potential candidates. The analysis will determine what content attributes affect the Engagement Index ${ }^{1}$ and the number of acquired resumes.

\subsection{The Content of the Analysed Recruitment Actions}

Figure 1. Recruitment announcement, 17 March 2017

Performics

17 marca $2017 \cdot 0$

Poszukujemy Account Managera! Jeżeli: masz min. 2-tetnie doświadczenie na podobnym stanowisku $w$ agencji interaktywnej lub doświadczenie na podobnym stanowisku w agencji interaktywnej lub reklamowej, znasz sois dighlal marketingu oraz ecommerce, potrafisz planowac i koordynowac projekty, tatwo nawiazzjesz kontakt i potrafisz budować długofalowe relacje z klientem i do tego wszystkiego liczenie i analiza danych nie stanowią dla Ciebie problemu, to wysilij swoje CV n adres: rekrutacja@publicismedia com, wpisując w tytule; Account

\#PerformicsPolska \#Rekrutacja \#AccountManage

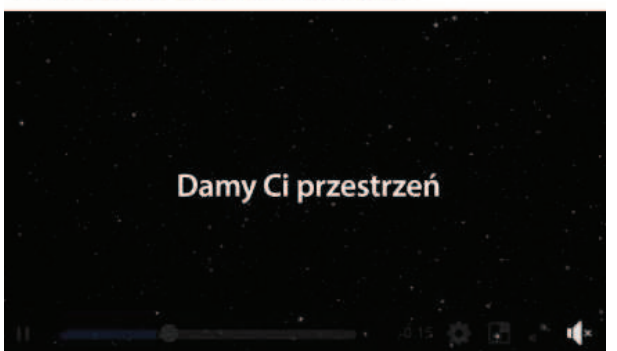

Translation: We're looking for an Account Manager! If you have at least 2 years of experience at a similar position in an interactive or marketing agency, if you know the world of digital marketing and e-commerce, if you know how to plan and coordinate projects, if you make contacts easily and can build long-term relations with the customers and, on top of that, counting and data analysis are just right up your alley, send your resume to the address: rekrutacja@publicismedia.com, subject: Account Manager.

We'll give you space

Source: Recruitment announcement by Performics (August 5, 2018).
Figure 2. Recruitment announcement, 3 August 2017

P) Performics

Zagraj o tron! Mistrzowie ASOP poszukiwani ASAP. Jeżeli jesteś technologicznym hardkorem, a Twoją zajawką są Analityka, Scoring, Optymalizacja i Prognozowanie - dołącz do nas! Performics, agencja marketingu efektywnościowego, szuka speców do ciekawej roboty. Jeżel jarają Cię internety, a różnica pomiędzy SEM i SEO nie jest dla Ciebie SEMantyka, uwielbiasz wygrywać i ogarniasz e-commerce to zdecydowanie pasujesz do naszej wesołej ferajny. Poszukujem kompetencji w obszarach SEM, SEO, Afiliacja, Paid Social, Programmatic, E-commerce. Zaoferujemy Ci imperium, które możesz z nami budować, realny rozwój samego siebie, ekipę zajawkowiczów i masę benefitów.

Audaces fortuna iuvat timidosque repellit. Podejmiesz wyzwanie? Sprawdź szczegóły:

Performance Planner: http://bit.ly/PerformancePlanner

Media Asisstant: http://bit.ly/MediaAssistantPFX

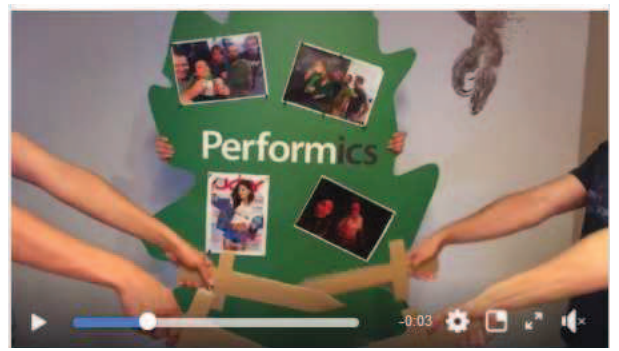

Translation: Play for the throne! Masters of ASOP needed ASAP. If you are into technology, hardcore and big time and your craze is Analytics, Scoring, Optimization and Prognostics - join us! Performics, performance marketing agency looks for pros in an interesting job. If you're psyched about the net, and the difference between SEM and SEO is not only the matter of SEMantics, if you love winning and you understand e-commerce, then you are definitely a match for our cheerful bunch. We are looking for competences in the field of SEM, SEO, Affiliation, Paid Social, Programmatic, E-commerce. In exchange we offer you an empire that you can build with us, actual self-development, passionate crowd and multiple benefits.

Audaces fortuna iuvat timidosque repellit. Will you take on the challenge?

Source: Recruitment announcement by Performics (August 5, 2018).

Figure 4 presents the first creative recruitment campaign in Poland, carried out by Publicis Media. Its main business goal was to broaden the brand awareness and increase the number of applicants to Performics. The marketing goal was to establish awareness in the segment of people aged 20-35 (Warsaw + around), i.e. among Generations $\mathrm{Y}$ and $\mathrm{Z}$, living close the company headquarters. But the media goal was an intensive campaign that promoted Performics as an attractive employer. Therefore, a Qualification Quiz 
Figure 3. Recruitment announcement, 16 November 2017
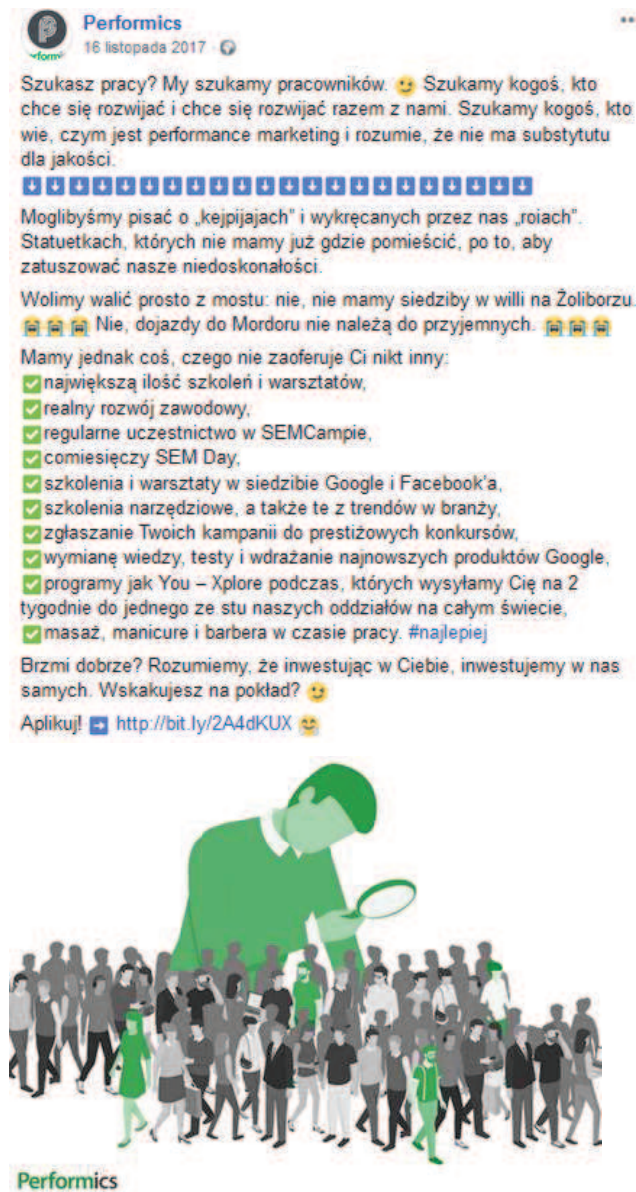

Translation: Are you looking for a job? Because we're hiring. We're looking for someone who wants to develop and wants to do it with us. We're looking for someone who knows what is performance marketing and that quality cannot be replaced.

We could write about KPIs and ROIs that we make. Statuettes that are too many to be hidden, but which hide our imperfections.

We pull no punches: no, we are not located in a villa in Żoliborz*, and yes - commutes to Mordor**are a nightmare. But what we have no one else can offer:

- The greatest number of trainings and workshops,

- Real professional development,

- Regular participation in SEMcamp,

- Monthly SEM Day,

- Trainings and workshops in Google and Facebook headquarters,

- Tool trainings, and trainings in branch trends,

- Submitting your campaigns in prestigious competitions,

- Knowledge sharing, tests and implementation of the newest Google products,

- Programs such as You-Xplore during which we send you off for two weeks to one of our 100 branch offices all over the world,

- Massages, manicures, barber during work hours. \#najlepiej

Sounds good? We understand that by investing in you, we invest in ourselves. Are you on board?

Apply!

*a district of Warsaw

**a nickname given to a hub of international corporations located in office buildings near Domaniewska Street in Warsaw

Source: Recruitment announcement by Performics (August 5, 2018).

Wydział Zarządzania UW https://doi.org/10.7172/1733-9758.2018.29.10 
Figure 4. Recruitment announcement by Performics, 14 December 2017

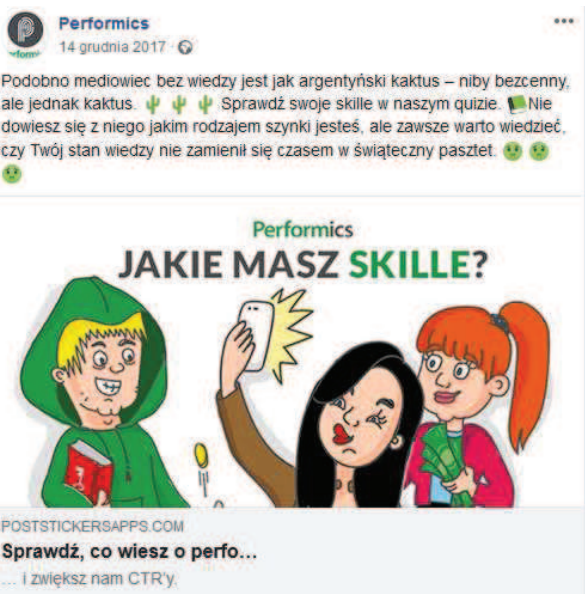

Translation: They say that a media person lacking knowledge is like an Argentinian cactus - supposedly priceless, but still a cactus. Check out your skills in our quiz. We won't tell you what type of ham you are, but it's always worth knowing if your knowledge has not changed into a Christmas pudding.

WHAT ARE YOUR SKILLS?

Check what you know about perfo...

... and raise our CTRs

Source: Recruitment announcement by Performics (August 8, 2018).

was created which checked the knowledge in four fields: Social Media, Programmatic, Marketing Automation and SEM. After answering 20 questions, randomly chosen by the system, it was verified in which field/fields the tested applicant had the best score and the system generated a funny take on the result (out of 10 available) that was sharable on the Facebook wall. Moreover, the person that took the test and answered all questions had the option to leave his or her data for application purposes.

\subsection{Analysis of the Content Attributes}

Below there is an analysis of the case study of Performics (Publicis Media) and a visualisation of recruitment posts placed on Facebook, complete with translations into English. All recruitment posts were addressed to people aged 20-35 (Generations $\mathrm{Z}$ and $\mathrm{Y}$ ) from Warsaw. Additionally, the campaign was narrowed down to people interested in digital marketing and
Figure 5. Exemplary questions taken from the Qualification Quiz

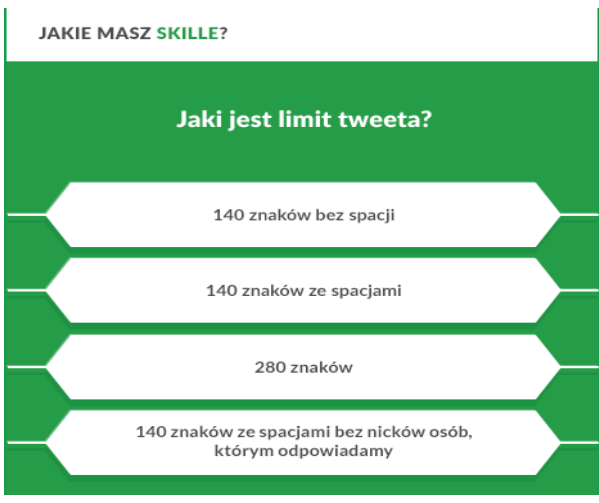

Translation: WHAT ARE YOUR SKILLS?

What is the tweet limit?

140 characters without spaces

140 characters with spaces

280 characters

140 characters with spaces without nicks of people we respond to

Source: Recruitment announcement by Performics (August 8, 2018).

working in competitive agencies. Consequently, the announcements were displayed only to a clear-cut target group.

Accepting the nomenclature by Palmatier et al. (2006), actions focused strictly on sales, and in the case of this analysis strictly of recruitment profile, concentrate only on the presentation of requirements of a given job, possibly on some benefits, and encourage people to apply for the described job. These actions do not consider the added values following from showing the atmosphere in the company, a sense of humour or the use of trends in a given branch, e.g. in the social media, digital. Figure 1 is a good example of such a recruitment announcement. It shows only the requirements of the job and encourages those meeting the specific criteria to apply.

Actions establishing relationships are the opposite of those focused strictly on sales (strictly of recruitment profile). In the case of such recruitment campaigns, apart from the naming of requirements and benefits, what is also shown are the fleeting aspects related to the atmosphere in a given company, such as in the announcement shown in Figure 2. The announcement 
Figure 6. One of the dedicated Qualification Quiz results.

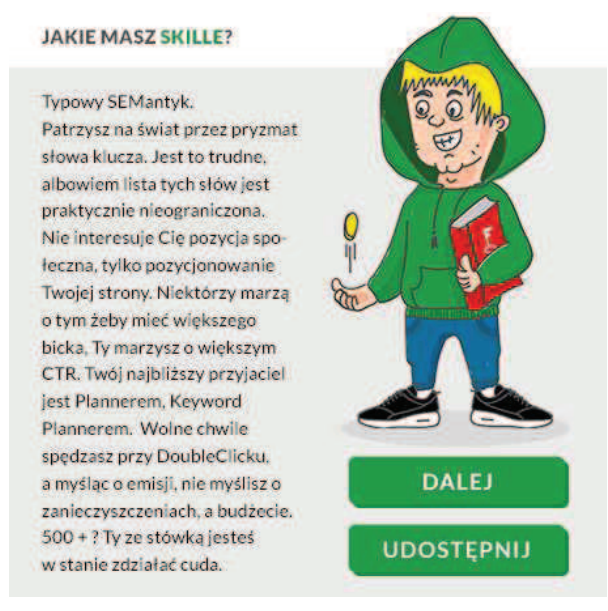

Translation: WHAT ARE YOUR SKILLS?

A typical SEManticist. Your angle to view the world is through keywords, which is a difficult task, as their list is virtually endless. You're not interested in your life optimization, but only in your Search Engine Optimization. Some dream of higher BIC, and you dream of higher CTR. Your best friend is a Planner, a Keyword Planner. You spend your free time with DoubleClick and the only casting you're interested in is broadcasting, meaning money. You and one hundred zlotys can do wonders.

NEXT

SHARE

Source: Recruitment announcement by Performics (August 8, 2018).

shows a clear sense of humour manifested in a copy with a grain of salt, but from it one can easily assume that there is a good atmosphere in the company and that teamwork is highly appreciated. Its premise is the image of the hands of employees holding paper swords as if to express the motto "One for all, all for one". Another example of the actions establishing relationships is in Figure 3. Although it applies a classical creative concept (creation), it uses a copy showing an honest approach of the company to its prospective employees, which is clear not from the fact that it names the requirements and benefits but it also laughingly admits that the company is in a very congested part of the town and that commute is a nightmare. Such actions demonstrate that the company is trustworthy and knows what difficulties and problems their employees have to face daily. This
Figure 7. Message displayed to those who wanted to share their data for recruitment purposes

\section{JAKIE MASZ SKILLE?}

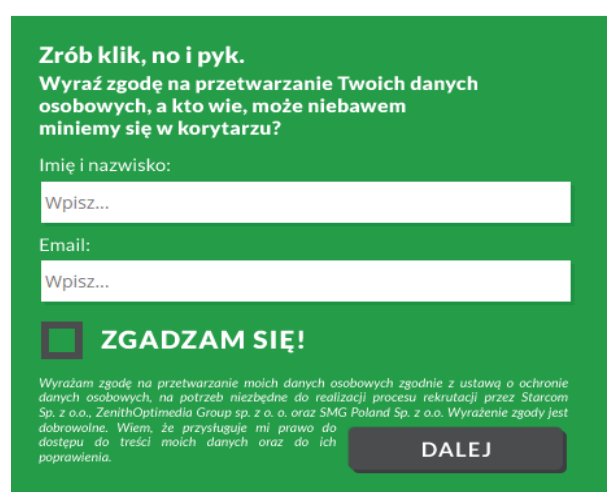

Translation: WHAT ARE YOUR SKILLS?

Just click and that's it.

Give your consent to the processing of your personal data and who knows - maybe next time we'll meet in the office corridors?

First and last name:

Enter...

E-mail:

Enter...

\section{AGREE!}

I agree to the processing of my personal data pursuant to the Personal Data Protection Act for the needs of the recruitment process by Starcom Sp. $z$ o.o., ZentihOptimedia Group Sp. z o.o. and SGM Poland Sp. $z$ o.o. Consent is voluntary. I'm aware that I have the right to access the contents of my personal data and to correct it. NEXT

Source: Recruitment announcement by Performics (August 8, 2018).

not only builds trust but also relations with the company because the company reveals its specificity already at the stage of the recruitment announcement. Figure 4 also presents actions establishing relationships as a very informal copy humorously informs that the atmosphere in the company is very relaxed.

On the other hand, actions based on deception (Martin \& Smith, 2008) are only loosely connected to a brand and/ or refer to a job offer only to a minimum degree. Figure 4 shows an example of such a recruitment announcement. It promoted a Qualification Quiz and only after its completion could the user make the results available on his/her wall or leave data for recruitment purposes. 


\section{Results}

The empirical research covering the preliminary logical analysis of results was used to investigate individual content attributes in relation to the engagement of young generation users in the recruitment posts generation users in the recruitment pos choice of research method was connected choice of research method was connected to a rather small number of observation (only four recruitment announcement were analysed). Therefore, the research made use of quality analyses in the form of a case study. The analysis of the case study results from the company named Perfor- mics (Publicis Media) indicates that emojis have a negative impact on the Engagement Index. But then, the more emojis there are in a recruitment announcement, the higher the number of acquired resumes/leads.

As the number of requirements increases, the Engagement Index increases as well, but the numer of lads drops. Mos wer, the num number of added values affects the number

It has to be also stated that listing the benefits in a recruitment announcement does not influence the Engagement Index and the number of leads in a significant way.

Table 3. Analysis of the content attributes

\begin{tabular}{|c|c|c|c|}
\hline & Content attributes & $\begin{array}{c}\text { Fig. 1. Recruitment } \\
\text { announcement, 17 March } 2017\end{array}$ & $\begin{array}{c}\text { Fig. 2. Recruitment } \\
\text { announcement, } 3 \text { August } 2017\end{array}$ \\
\hline \multirow{4}{*}{ 突 } & Format & Video & Video (Gif) \\
\hline & Video length & 24 seconds & 4 seconds \\
\hline & Application form & $\begin{array}{l}\text { Sending an e-mail to a given } \\
\text { e-mail address }\end{array}$ & $\begin{array}{l}\text { Forwarding to erecruiter.pl } \\
\text { application form }\end{array}$ \\
\hline & Readability & $\begin{array}{l}\text { Generally understandable } \\
\text { message }\end{array}$ & $\begin{array}{l}\text { Message understandable only to } \\
\text { specialists in a given field }\end{array}$ \\
\hline \multirow{5}{*}{ 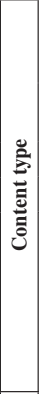 } & \begin{tabular}{|l|} 
Length of the \\
message (characters \\
without spaces)
\end{tabular} & 460 & 743 \\
\hline & Use of hashtags (\#) & $\begin{array}{l}\text { \#PerformicsPolska \#Rekrutacja } \\
\text { \#AccountManager }\end{array}$ & $\mathrm{n} / \mathrm{a}$ \\
\hline & Number of hashtags & 3 & 0 \\
\hline & Number of emojis & 0 & 0 \\
\hline & $\begin{array}{l}\text { Cohesion of the } \\
\text { message }\end{array}$ & $\begin{array}{l}\text { Video and content form a clear } \\
\text { message but the entirety does } \\
\text { not contain coherent details. }\end{array}$ & $\begin{array}{l}\text { The content does not correspond } \\
\text { to the video. Video presents } \\
\text { the team and elements } \\
\text { understandable only to those } \\
\text { employed within the organization. } \\
\text { For those who do not work within } \\
\text { it the message is unclear. }\end{array}$ \\
\hline 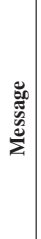 & Listed requirements & $\begin{array}{l}\text { - Minimum } 2 \text { years of } \\
\text { experience in a similar } \\
\text { position in an interactive or } \\
\text { marketing agency, } \\
\text { - You know the world of digital } \\
\text { marketing and e-commerce, } \\
\text { - You know how to plan and } \\
\text { coordinate projects, }\end{array}$ & $\begin{array}{l}\text { - ASOP Masters } \\
\text { - If you are into technology, } \\
\text { hardcore and big time, } \\
\text { - Your craze is Analytics, Scoring, } \\
\text { Optimization and Prognostics, } \\
\text { - If you're psyched about the net, } \\
\text { - The difference between SEM } \\
\text { and SEO is not a matter of } \\
\text { SEMantics, }\end{array}$ \\
\hline
\end{tabular}

The analysis of recruitment campaigns carried out by Performics company (Publicis Media) in 2017 shows that the most effective campaign was the one presented in Figure 4 (Recruitment announcement in 14 (Recruin) of 14 December 2017), because the CPL (Cost Per Lead) was the cheapest of al This campaign shows that in this case study the actions based on establishing relationships and on deception allow acquirement of the highest number of leads and have
the lowest CPL (Table 4). Therefore, the most effective announcement was the one presented in Figure 4, in which the message was not clear that it was a recruitment announcement and which presented no data about requirements and benefits.

Moreover, the analysis shows that the CPA was lower than for the strictly seling campainn (Figure 1) compared to he relations ( hich is presented in Table 4 . It might be we result of the Facebook index, i.e. Post

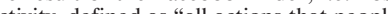
activity, defined as "all actions that people take involving your ads while they're running. Post activity can include actions such as reacting to, commenting on or sharing the ad, claiming an offer, viewing a photo or video, or clicking on a link" (Facebook Business). Table 3 and Table 4 show that

\begin{tabular}{|c|c|}
\hline $\begin{array}{l}\text { Fig. 3. Recruitment announcement, } \\
16 \text { November } 2017\end{array}$ & $\begin{array}{l}\text { Fig. 4. Recruitment announcement, } \\
14 \text { December } 2017\end{array}$ \\
\hline Image & Image (Quiz) \\
\hline $\mathrm{n} / \mathrm{a}$ & $\mathrm{n} / \mathrm{a}$ \\
\hline $\begin{array}{l}\text { Forwarding to Career tab on http:// } \\
\text { publicismedia.pl/, where all the current job } \\
\text { offers are posted }\end{array}$ & $\begin{array}{l}\text { After completing the Quiz, the user was able } \\
\text { to type his/her first and last name and e-mail } \\
\text { address if he or she wanted a recruiter to } \\
\text { contact him or her regarding job offers }\end{array}$ \\
\hline Generally understandable message & $\begin{array}{l}\text { Message understandable only to specialists in } \\
\text { a given field }\end{array}$ \\
\hline 1,066 & 241 \\
\hline \#najlepiej & $\mathrm{n} / \mathrm{a}$ \\
\hline 1 & 0 \\
\hline 41 & 7 \\
\hline $\begin{array}{l}\text { The graphics in a clear way shows that the } \\
\text { company is looking for new employees but } \\
\text { it might be done in a less formal way to be } \\
\text { coherent with the content of the message. }\end{array}$ & $\begin{array}{l}\text { The graphics, message and content of the quiz } \\
\text { and application form are connected to each } \\
\text { other and form a coherent entirety. }\end{array}$ \\
\hline $\begin{array}{l}\text { - We're looking for someone who wants to } \\
\text { develop and wants to do it with us, } \\
\text { - We're looking for someone who knows what } \\
\text { is performance marketing and that quality } \\
\text { cannot be replaced }\end{array}$ & $\mathrm{n} / \mathrm{a}$ \\
\hline
\end{tabular}

Wydział Zarządzania UW https://doi.org/10.7172/1733-9758.2018.29.10 


\begin{tabular}{|c|c|c|c|}
\hline & Content attributes & $\begin{array}{c}\text { Fig. 1. Recruitment } \\
\text { announcement, } 17 \text { March } 2017\end{array}$ & $\begin{array}{c}\text { Fig. 2. Recruitment } \\
\text { announcement, } 3 \text { August } 2017\end{array}$ \\
\hline \multirow{7}{*}{ 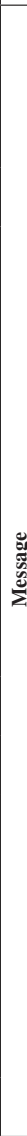 } & & $\begin{array}{l}\text { - You make contacts easily, } \\
\text { - You can build long-term } \\
\text { relations with the customers, } \\
\text { - Counting and data analysis } \\
\text { are just right up your alley }\end{array}$ & $\begin{array}{l}\text { - You love winning, } \\
\text { - You understand e-commerce, } \\
\text { - We're looking for qualification } \\
\text { in SEM, SEO, Affiliation, Paid } \\
\text { Social, Programmatic and } \\
\text { E-commerce }\end{array}$ \\
\hline & $\begin{array}{l}\text { The number of } \\
\text { listed requirements }\end{array}$ & 6 & 8 \\
\hline & Listed benefits & $\mathrm{n} / \mathrm{a}$ & $\begin{array}{l}\text { - We offer you the possibility to } \\
\text { build an empire with us, } \\
\text { - Actual self-development, } \\
\text { - Passionate crowd, }\end{array}$ \\
\hline & $\begin{array}{l}\text { Number of listed } \\
\text { benefits }\end{array}$ & 0 & 3 \\
\hline & $\begin{array}{l}\text { Requirement:benefit } \\
\text { ratio }\end{array}$ & 6:0 & $8: 3$ \\
\hline & Added value & $\mathrm{n} / \mathrm{a}$ & $\mathrm{n} / \mathrm{a}$ \\
\hline & $\begin{array}{l}\text { Amount of added } \\
\text { values }\end{array}$ & 0 & 0 \\
\hline
\end{tabular}

\begin{tabular}{|c|c|}
\hline $\begin{array}{l}\text { Fig. 3. Recruitment announcement, } \\
16 \text { November } 2017\end{array}$ & $\begin{array}{l}\text { Fig. 4. Recruitment announcement, } \\
14 \text { December } 2017\end{array}$ \\
\hline 2 & 0 \\
\hline $\begin{array}{l}\text { - The greatest number of trainings and } \\
\text { workshops, } \\
\text { - Real professional development, } \\
\text { - Regular participation in SEMcamp, } \\
\text { - Monthly SEM Day, } \\
\text { - Trainings and workshops in Google and } \\
\text { Facebook headquarters, } \\
\text { - Tool trainings, and trainings in branch trends, } \\
\text { - Submitting your campaigns in prestigious } \\
\text { competitions, } \\
\text { - Knowledge sharing, tests and implementation } \\
\text { of the newest Google products, } \\
\text { - Programs such as You-Xplore during which } \\
\text { we send you off for two weeks to one of our } \\
100 \text { branch offices all over the world, } \\
\text { - Massages, manicures, barber during work } \\
\text { hours }\end{array}$ & n/a \\
\hline 9 & 0 \\
\hline 2:9 & $0: 0$ \\
\hline $\mathrm{n} / \mathrm{a}$ & $\begin{array}{l}\text { - Checking the knowledge in all of the four } \\
\text { fields: Social Media, Programmatic, SEM, } \\
\text { Marketing Automation. The person doing } \\
\text { the test is not able to check which questions } \\
\text { were answered correctly and which were } \\
\text { not. } \\
\text { - Verification if one has competences } \\
\text { required in order to work at Performics. } \\
\text { - Chance to publish the results in the form of } \\
\text { a funny image and amusing description on } \\
\text { Facebook wall }\end{array}$ \\
\hline 0 & 3 \\
\hline
\end{tabular}

Source: Own study. 
Table 4. Results of recruitment campaigns

\begin{tabular}{|c|c|c|c|c|c|c|c|c|c|c|}
\hline & 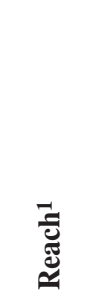 & 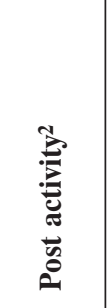 & 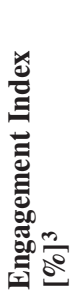 & 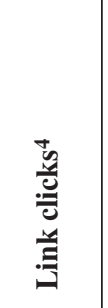 & $\frac{\frac{n}{2}}{\frac{a}{5}}$ & 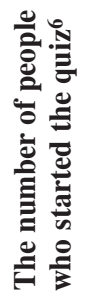 & 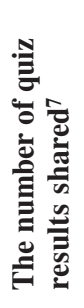 & 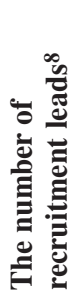 & 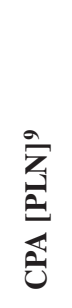 & 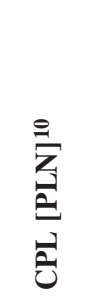 \\
\hline Figure 1 & 20,820 & 1,145 & $5 \%$ & $\mathrm{n} / \mathrm{a}$ & $\mathrm{n} / \mathrm{a}$ & $\mathrm{n} / \mathrm{a}$ & $\mathrm{n} / \mathrm{a}$ & 1 & 0.14 & 170.00 \\
\hline Figure 2 & 33,589 & 9,540 & $28 \%$ & 7 & 0.01 & $\mathrm{n} / \mathrm{a}$ & $\mathrm{n} / \mathrm{a}$ & 2 & 0.03 & 150.00 \\
\hline Figure 3 & 23,308 & 341 & $1 \%$ & 218 & 0.59 & $\mathrm{n} / \mathrm{a}$ & $\mathrm{n} / \mathrm{a}$ & 13 & 1.46 & 38.46 \\
\hline Figure 4 & 38,495 & 1,052 & $3 \%$ & 1,138 & 1.16 & 1,270 & 700 & 113 & 1.14 & 10.62 \\
\hline
\end{tabular}

1 Reach is the number of people who saw the recruitment post.

2 Post activity is a joint number of actions taken by persons who saw the recruitment posts.

3 Engagement Index is the ratio between the number of people who saw the announcement (Reach) and the activity concerning the post (Post activity) that is measured in percentage.

4 Link clicks is the number of link clicks on the announcement that redirected to the target location or contents on or off Facebook.

5 CTR is the ratio between the number of clicks and display of the advertisement measured in percentage.

6 Number of people who have started the quiz in the recruitment campaign by Performics (Figure 4).

7 Number of people who have shared their quiz results on their private Facebook wall. Figure 6 gives an example of the quiz result.

8 Number of people who have left their data for recruitment purposes.

9 CPA (Cost Per Action) is the cost for unit activity towards the post expressed in PLN.

10 CPL (Cost Per Lead) is the cost for unit data left for recruitment purposes expressed in PLN.

Source: Own study based on the results of recruitment campaigns.

the recruitment announcements in the form of a video have a significantly lower CPA than those in a graphical form. While analysing this indicator, it has to be remembered that the video opens automatically and the GIF is looped (it is played again and again), so Facebook might count more engagement compared to the actual level.

Additionally, the analysis of this case study shows that actions establishing relationships (Figure 4) result in lower costs of acquiring a lead (CPL - Cost Per Lead) than actions of a strictly selling profile, not listing any benefits, only requirements (Figure 1), and have lower CPL than selling actions that have more benefits than requirements (Figure 3 ).

The CPA is lower for strictly selling campaigns in the form of a video. However, the analysis indicates that $55 \%$ $(700 / 1270=0.55)$ of those who took the quiz (Figure 4) shared the results on their Facebook wall.
Furthermore, actions based on deception (Figure 4) result in lower costs of acquiring a lead (CPL - Cost Per Lead) than actions of a strictly selling profile, not listing any benefits, only requirements (Figure 1), and have lower CPL than selling activities that have more benefits than requirements (Figure 3).

\section{Discussion and Conclusions}

The presented analysis indicates that the most engaging recruitment announcements are videos, at least based on the Post activity indicator. However, this indicator refers only to interactions with the published announcement and does not take into account starting the Qualification Quiz or sharing its results on the Facebook wall (Figure 4). The analysis confirms that actions based on establishing relationships and on deception allow acquiring more resumes than those focused strictly 
on sales (strictly of recruitment profile). The empirical analysis indicates that although the younger generations declare that the benefits (like trainings, workshops, self-development) are very important to them, the relation between benefits and engagement and acquired leads is rather faint. On the other hand, the added values have a significant influence on the number of acquired leads, which is identical to relationship building and deception actions. Moreover, the use of emojis also had a significant influence on the lead numbers but at the same time they had a negative impact on the engagement level.

Therefore, it is possible to accept initial conclusions regarding the effectiveness of recruitment campaigns targeted at Generation $\mathrm{Z}$ based on the case study according to which employers who want to acquire lots of leads have to use added values and emojis in their recruitment announcements. They should avoid listing too many requirements and use as little hashtags as possible.

The analysis indicates that higher engagement in the post does not translate to a higher number of acquired leads.

\subsection{Research Restrictions}

The research restrictions include the fact that it was based only on four recruitment campaigns targeted at people aged 20-35 (Generations Z and Y) from Warsaw and around. Another restriction was the diversified timespan and convention of the announcements, which differed not only in form and application form but also in the position offered. The author is aware that the data on how many were really employed as a result of the analysed recruitment campaigns would be extremely useful. However, because of the company's policy and the privacy law, such information cannot be included in this article. Moreover, it is necessary to conduct further research to find out which content attributes are responsible for effectiveness of the recruitment campaign.

\subsection{Further Direction of Research}

In the next research, the author would like to analyse a recruitment campaign in few versions (relationship building, deception and strictly selling), directed to all the generations active on the labour market. Then, the author would like to verify, in a correlation analysis, if there is a relation between specific content attributes and engagement in the posts and the number of leads acquired from specific generations. The next step of the research would be a survey directed to the representatives of all the generations active on labour market in order to state what they really focus on in recruitment announcements and what is most important to them. The author presumes that because of that every generation has different values and different elements influence their engagement in the post and whether they send resumes or not.

As a result, the author formulates hypotheses on the basis of the case study which she would like to verify in subsequent research.

\section{Research Hypotheses:}

\section{Hypothesis \#1}

Actions consisting in establishing relationships are more engaging than those focused strictly on sales (strictly of recruitment profile).

\section{Hypothesis \#2}

Actions consisting in establishing relationships allow acquiring a higher number of resumes than those focused strictly on sales (strictly of recruitment profile).

\section{Hypothesis \#3}

Actions based on deception are more engaging than those focused strictly on sales (strictly of recruitment profile).

\section{Hypothesis \#4}

Actions based on deception allow acquiring a higher number of resumes than those focused strictly on sales (strictly of recruitment profile).

\section{Endnotes}

1 The ratio between the number of people who saw the advertisement (Reach) and the activity concerning the post (Post activity) that is measured in percentage.

\section{References}

Berry, L.L. (1983). Relationship marketing. In L.L. Berry, G.L. Shostack, \& G.D. Upah (Eds.), Emerging perspectives on services marketing (pp. 25-28). Chicago: American Marketing Association. 
Bizzi, L. (2018). The hidden problem of Facebook and social media at work: What if employees start searching for other jobs?. Business Horizons 61 23-33. https://doi.org/10.1016/j.bushor.2017.09.002.

Cho, J., Park, D.J., \& Ordonez, Z. (2013). Communication-oriented person - organization fit as a key factor of job-seeking behaviors: Millennials' social media use and attitudes towards organizational social media policies. Cyberpsychology, Behavior, and Social Networking, 16(11), 794-799. https://doi. org/10.1089/cyber.2012.0528.

Cober, R.T., Brown, D.J., Keeping, L.M., \& Levy, P.E. (2004b). Recruitment on the Net: How do organizational web site characteristics influence applicant attraction? Journal of Management, 30(5), 623-646. https://doi.org/10.1016/j.jm.04.03.001. ISSN 01492063.

David, M.S. (2010). The new rules of marketing and PR: How to use social media, blogs, news releases, online video, and virtual marketing to reach buyers directly. Hoboken, NJ: John Wiley \& Sons.

Drapała, B. (2019). Jak dotrzeć do pokolenia Z i zaangażować w je w komunikację korporacyjna marki? Social Media Manager, 1(9), 31-33.

Facebook Business, Facebook Advertising help Retrieved from: https:/www.facebook.com/business/help/735720159834389 (01.08.2018).

Grönroos, Ch. (1994). From marketing mix to relationship marketing: Towards a paradigm. Journal of Marketing Management, 10(5), 347-360.

Hallahan, K., Holtzhausen, D., van Ruler, B. Vertic, D., \& Sriramesh, K. (2007). Defining strategic communication. International Journal of Strategic Communication, 1(1), 3-35. https://doi org/10.1080/15531180701285244.

https://www.facebook.com/PerformicsPL/pho tos/a.1826203924315964.1073741828.18252120310818 20/2017836391819382/?type $=3$ (05.08.2018).

https://www.facebook.com/PerformicsPL/posts/ 2034089123527442 (08.08.2018).

https://www.facebook.com/PerformicsPL/videos/ 1879006175702405/ (05.08.2018)

https://www.facebook.com/PerformicsPL/videos/ 1964396887163333/ (05.08.2018)

Jansen, B.J., Jansen, K.J., \& Spink, A. (2005). Using the Web to look for work - Implications for online job seeking and recruiting internet research. Journal of Internet Research, 15(1), 49-66.

Jobvite. (2013). Social recruiting survey results Retrieved from: http://web.jobvite.com/rs/jobvite/ images/Jobvite_2013_SocialRecruitingSurveyResults.pdf (05.07.2018).
Karim, M.R., Miah, Sh., \& Khatun, A. (2015). E-recruitment in practice: A study on jobseekers' perception in Bangladesh. Global Disclosure of Economics and Business, 4(I), 36.

Kerrin, M. (2005). E-based recruitment: New challenges in the application of selection and assessment Paper presented at the Division of Occupational Psychology Conference, Warwickshire, UK.

Leńczuk, J. (2018). Litery dzielace generacje o różnicach między pokoleniem X, Y i Z. Retrieved from: http://stapler.pl/hydepark/litery-dzielacegeneracje-o-roznicach-miedzy-pokoleniem-x-y (04.08.2018)

Levitt, T. (1983). After the sale is over. Harvard Business Review, 61(5), 87-93.

Martin, K., \& Smith, C. (2008). Commercializing social interaction: The ethics of stealth marketing. Journal of Public Policy \& Marketing, 27(1), 45-56. https://doi.org/10.1509/jppm.27.1.45.

Palmatier, R.W., Dant, R.P., Grewal, D., \& Evans, K.R. (2006). Factors influencing the effectiveness of relationship marketing: A meta-analysis. Journal of Marketing, 70(4), 136-153.

Raport Media Społecznościowe w rekrutacji, edycja druga. Retrieved from: https://bit.ly/2HESKJ8 (01.08.2018).

Tiago, M., T., P., M., B., \& Verissimo, J., M.C. (2014). Digital marketing and social media: Why bother? Business Horizons, 57(6), 703-708.

Trębała, J., \& Harwas-Napierała, B. (2004). Psy chologia rozwoju człowieka. Charakterystyka okresów zycia człowieka. Tom 2. Warszawa: WN PWN.

Walków, M. (2018). Pokolenia na rynku pracy w Polsce - kim są baby boomers, X, Y i C? Retrieved from: https://businessinsider.com.pl/ rozwoj-osobisty/kariera/millenials-pokolenie-x-yz-i-baby-boomers-kim-sa-na-rynku-pracy/6e $531 \mathrm{mr}$ (04.08.2018).

Williamson, I.O., King Jr, J.E., Lepak, D., \& Sarma, A. (2010). Firm reputation, recruitment web sites, and attracting applicants. Human Resources Management, 49(4), 669-687.

Wiśniewski, P. (2016). Marketing - relacja wymiana wartości. In: K. Klincewicz (Ed.), Zarzadzanie, organizacje $i$ organizowanie. Przeglad perspektyw teoretycznych. Warszawa: Wydawnictwo Naukowe Wydziału Zarządzania UW.

Zaborek, P. (2007). Studium przypadku jako metoda badawcza pracy doktorskiej. In: K. Kuciński (Ed.), Doktoranci o metodologii nauk ekonomicznych (pp. 265-277). Warszawa: Oficyna Wydawnicza SGH. 